\title{
PERAN GURU SEJARAH DALAM PENDIDIKAN KARAKTER DI ERA REVOLUSI INDUSTRI 4.0
}

\author{
Suyanti \\ Universitas PGRI Madiun \\ yantiee.nathan@gmail.com
}

\begin{abstract}
Abstrak
Guru adalah pendidik profesional dengan tugas mengajar, mendidik, membimbing, melatih, dan menilai peserta didik. Peran guru sejarah semakin kompleks pada era Revolusi 4.0. Guru bukan hanya dituntut untuk menguasai materi pembelajaran maupun kompetensi penunjang pembelajaran, namun guru juga dituntut untuk mananamkan karakter nasionalisme. Di era revolusi 4.0 perkembangan teknologi semakin cepat dan guru sejarah diharapkan tidak hanya memberikan ilmu pengetahuan saja tetapi harus menginternalisasi nilai-nilai karakter yang tidak bisa digantikan oleh teknologi secanggih apapun. Maka dari itu, sebagai guru sejarah harus bisa mengembangkan kompetensinya mengikuti perkembangan zaman dan bisa memainkan peran demi keberhasilan belajar peserta didik.
\end{abstract}

Kata kunci: Guru sejarah, pendidikan karakter, Revolusi Industri 4.0

\begin{abstract}
The teacher is a professional educator which has the task of teaching, educating, guiding, training, and assessing students. The role of history teacher is increasingly complex in the 4.0 Revolution era. Teachers are not only required to master learning materials and learning support competencies, but teachers are also required to instill the character of nationalism. In 4.0 revolution era, the development of technology is accelerating and history teacher expect to not only provide knowledge but must internalize the values of characters that cannot be replaced by any sophisticated technology. Therefore, as a history teacher must be able to develop competence to keep abreast of the times and can play a role for the success of students' learning.
\end{abstract}

Key words: History teachers, character education, Industrial Revolution 4.0.

\section{PENDAHULUAN}

Peran guru dalam di kemajuan pendidikan sangat besar, hal ini karena guru menjadi barisan terdepan dalam proses belajar mengajar. Saat ini guru mempunyai peran dan tanggung jawab yang cukup besar, baik mengenai standar 
dalam kegiatan pembelajaran, juga mengembangkan berpikir peserta didik yang kritis. Guru dihadapkan pada tantangan era revolusi industry 4.0, dituntut tidak hanya mampu beradaptasi dengan zaman, tetapi mampu menguasai teknologi agar bisa menyesuaikan dengan peserta didik. Walaupun perkembangan dalam pendidikan belum secara optimal mengikuti kecepatan dalam era revolusi industri 4.0 tetapi perlu upaya yang harus dilakukan dalam menghadapi era revolusi industry 4.0 yaitu peningkataan kualitas seorang guru agar menjadi guru yang profesional sesuai tuntutan zaman (Kompasiana.com, 3 juni 2019).

Di era revolusi industry 4.0 ini guru di tuntut tidak hanya mengajarkan pengetahuan saja tetapi juga internalisasi nilai kepada peserta didik, khususnya guru sejarah. Guru sejarah disamping mengajarkan pengetahuan sesuai dengan kebenaran dan sesuai fakta juga berperan dalam menumbuhkan kesadaran sejarah peserta didik, kesadaran sejarah merupakan bagian dari nilai karakter. Guru sejarah mempunyai peran penting dalam pendidikan karakter sesuai dengan Permen No 16 tahun 2007 tentang standar Kualifikasi dan Kompetensi Guru yaitu: "guru sejarah harus bisa menguasai struktur ilmu, ruang lingkup, dan dapat membedakan pendekatan-pendekatan dalam sejarah, mampu menguasai materi dengan cakupan yang luas, serta dapat menyajikan tentang manfaatnya". Internalisasi nilai-nilai oleh guru terhadap peserta didik tidak dapat digantikan dengan mesin. Berdasar uraian tersebut, tulisan ini mengkaji mengenai peran guru sejarah dalam pendidikan karakter di era Revolusi industry 4.0.

\section{METODE}

Artikel ini merupakan telaah atau review dari berbagai sumber pustaka yang dihimpun penulis. Literaratur yang dikaji dikaitkan dengan realitas lapangan atau konteks pendidikan saat ini, terutama dengan peran guru sejarah dalam menghadapi tantangan revolusi industry 4.0. 


\section{HASIL DAN PEMBAHASAN}

\section{Peran Guru Sejarah}

Guru secara sederhana dimaknai mengajarkan ilmu pengetahuan kepada peserta didik. Dalam pandangan masyarakat, guru dianggap sebagai ahli dalam bidang tertentu. Guru merupakan pendidik yang sudah profesional, dengan tugastugasnya antara lain mendidik dan juga mengajarkan serta melatih dan menilai pada pendidikan formal. Guru merupakan unsur penting dalam pendidikan, apabila guru tidak profesional, maka dapat dipastikan kualitas peserta didik tidak akan maksimal. Guru profesional harus selalu mengembangkan kompetensinya di bidang akademik serta melek teknologi terbaru dan pengembangan tersebut dilakukan secara kontinyu. Guru di katakan kompeten apabila keahliannya sesuai dengan bidang yang di ampu dan di peroleh melalui pelatihan-pelatihan atau pendidikan.

Peran guru sangat kompleks dan multifungsi, tak terkecuali guru sejarah. Ia harus mampu membelajarkan peserta didik baik melalui aspek pengetahuan, afektif, maupun psikomotor. Peran dan tugas yang diemban guru tidak bisa dipisahkan antara satu dan lainnya. Semua itu harus ada dalam kompetensi seorang guru, yang kemudian diajarkan kepada peserta didiknya. Maka dari itu, seorang guru harus menjadi guru yang profesional, paham akan kedudukan, peranannnya baik pada saat pembelajaran atau di luar pembelajaran.

Guru sejarah mampu mengembangkan pendidikan yang mendorong kemajuan peserta didik dengan cara merancang pembelajaran yang tidak membosankan dan menarik bagi peserta didik. Guru sejarah harus mengembangkan kompetensinya, baik mengenai penguasaan materi maupun penguasaan teknik, sehingga pembelajaran dapat berjalan dengan efektif. Peranan guru sejarah antara lain: (1) mendidik, membimbing serta guru sebagai motivator agar tujuan pembelajaran dapat tercapai, (2) guru dapat memberikan fasilitas dalam ketercapaian tujuan pembelajaran secara efektif, (3) guru harus bisa menumbuhkembangkan potensi peserta didik, baik sikap ataupun nilai-nilai 
peserta didik, menodorng peserta didik untuk aktif serta kreatif dalam pembelajaran (Slameto, 2015).

\section{Pendidikan Karakter}

Karakter menunjukkan pribadi orang dalam bertingkah laku. Apabila orang bertingkah laku buruk maka pribadi orang itu memanifestasikan tingkah laku buruk dan sebaliknya. Orang bisa dikatakan berkarakter apabila orang tersebut bertingkah laku sesuai nilai moral. Karakter tentu saja buah hasil dari belajar bukan didapat dengan cara instan. Karakter yang baik harus tetap di bangun terus menerus dan setiap orang yang berkarakter tidak sama satu dengan yang lain.

Karakter merupakan cara berikir dan bertindak dari seorang individu, dalam menjalani hidup dan berinteraksi baik dari lingkungan keluarga maupun masyarakat yang luas. Karakter dimaknai sebagai nilai-nilai perilaku yang berinteraksi dengan Tuhan, sesama manusia, dan lingkungan sekitar, berdasar norma-norma yang berlaku di masyarakat (Samani \& Hariyanto, 2013). Sedangkan menurut John Luther dalam Megawangi (2007) karakter yang baik itu pantas diberi pujian daripada bakat yang luar biasa. Memang sebagian besar bakat itu anugerah, seseorang yang mempunyai karakter yang baik itu tidak didapatkan secara instan tetapi sedikit demi sedikit dan perlu usaha yang keras untuk mendapatkannya.

Megawangi (2007) menyebutkan bahwa pendidikan karakter bisa dimaknai sebagai suatu usaha agar anak didik dapat mengambil keputusan secara bijak dan dapat di terapkan dalam kehidupannya, sehingga mempunyai feedback yang positif baik terhadap diri sendiri maupun lingkungan (Kesuma, 2013). Pendidikan karakter diajarkan oleh guru kepada peserta didiknya untuk mengembangkan kemampuan anak didik mengenai baik buruk, menjaga hal baik tersebut, dan memunculkannya dalam kehidupan sehari-hari. Sejalan dengan pendapat Asmani (2013), pendidikan karakter yang diterapkan secara terus menerus dan sistematis dapat meningkatkan kecerdasan emosi anak. Kecerdasan emosi peserta didik 
dapat digunakan untuk mengahadapi tantangan dalam kehidupan khusunya tantangan akademik.

Menurut Ryan and Lickona (1992) pendidikan karakter harus melibatkan ranah pengetahuan, afektif dan psikomotorik. Tanpa ketiga ranah tersebut menumbuhkan kembangkan nilai karakter dalam diri peserta didik tidak akan efektif (Jamal, 2011). Pelaksanaan pendidikan karakter mempunyai tujuan yang antara lain: (1) menumbuhkembangkan potensi afektif yang dimiliki oleh peserta didik, agar menjadi warga negara mempunyai karakter yang baik, (2) mengembangkan perilaku serta kebiasaan dalam hidup sehari-hari disesuaikan dengan nilai sikap, perilaku, dan kebiasaan yang ada dalam hidup masyarakat pada umumnya, (3) menanamkan sikap kepemimpinan serta tanggung jawab untuk menjadi pewaris atau penerus di generasi yang akan datang, (4) menumbuhkembangkan sikap mandiri dan kreatif yang tinggi serta berwawasan kebangsaan, (5) menumbuhkembangkan lingkungan sekolah sebagai lingkungan yang aman untuk belajar, lingkungan yang kreatif, dan kebangsaan dengan kekuatan penuh (Puskur, 2010).

\section{Era Revolusi Industri 4.0}

Revolusi indutri 4.0 berawal dari proyek oleh Jerman yang mempromosikan computer manufaktur (Yahya, 2018). Era revolusi 4.0 ini atau revolusi digital dan disrubsi dapat dimaknai sebagai inovasi, perubahan di setiap sendi kehidupan manusia (Kasasi, 2018). Di era revolusi industri 4.0 mampu merubah pekerjaan dan kebutuhan kompetensi yang diperlukan dalam pekerjaan. Hermann et. al dalam Yahya (2018) menyatakan bahwa ada empat prinsip desain revolusi industry 4.0, antara lain: (1) interkoneksi, yakni sambungan mesin, sensor, perangkat yang menghubungkan seseorang berkomunikasi dengan orang lain, (2) transparansi, yakni kemampuan sistem informasi dalam menciptakan salinan virtual dengan cara memperluas model digital melalui data sensor, (3) kemampuan system teknis, antara lain kemampuan system yang membantu manusia dalam mengolah dan mengevaluasi informasi sebagai upaya memecahkan masalah dan mengambil kebijakan yang tepat, serta membantu 
manusia membuat tugas jadi menyenangkan, (4) terdesentralisasi, yaitu kemampuan dari sistem dalam mengambil keputusan dengan bijak.

Era Revolusi industry 4.0 atau disebut juga era digital merupakan pengaplikasian kecerdasann buatan. Disebut demikian karena era dimana robot dijadikan pengganti dari tenaga manusia yang sangat efisien. Kemajuan era ini terjadi di semua lini kehidupan dan akan mengubah apa yang menjadi pola hidup masyarakat dan hubungan interaksi antar manusia dalam masyarakat (Tjandrawina, 2016).

Era revolusi 4.0 menghasilkan otomasi teknologi yang disebut cyber physical system yaitu system yang dalam pengoperasiannya dimonitor, dan dikendalikan dengan komunikasi (Ragunathan, 2010). System ini sudah memasuki hampir semua aspek kehidupan dan menjadi tantangan tersendiri dalam dunia pendidikan. Era Revolusi Industri 4.0 merubah konsep pekerjaan, kompetensi yang diperlukan dalam pekerjaan, bahkan mengubah tentang sudut pandang dalam pendidikan. Perubahan yang terjadi bukan hanya mengenai pola mengajar, tetapi mengenai konsep pendidikan itu sendiri. Era revolusi industri 4.0 merupakan tantangan yang sangat berat, apabila tidak mengubah cara lama dalam mengajar tentunya akan tertinggal dari negara-negara yang sudah dahulu menerapkan era ini. Peran guru tidak hanya memberikan pengetahuan saja, tetapi sikap, keterampilan, dan pengembangan karakter juga harus diajarkan kepada peserta didik dan kelak tidak bisa digantikan dengan robot.

Di era revolusi industry 4.0 kemajuan bidang teknologi sangat cepat yang disertai dengan kemudahan-kemudahan. Ini berimplikasi pada bidang pendidikan yang menuntut perubahan sistem pembelajaran lama menjadi pembelajaran berbasis teknologi. Oleh karena itu, guru sejarah dituntut mampu menjalankan peran dan tugasnya dengan semaksimal mungkin, sesuai dengan tantangan di era revolusi industri 4.0. Sehubungan dengan hal itu, dalam bidang pendidikan di era revolusi 4.0 terdapat 10 kecenderungan (Nasbit, 2018), antara lain: (1) perubahan masyarakat industry ke masyarakat sarat akan informasi, (2) perubahan teknologi standar ke teknologi ke tingkat tinggi, (3) perubahan dari system ekonomi 
nasional ke ekonomi yang lebih luas, yaitu dunia, (4) perubahan dari perencanaan jangja pendek ke jangka panjang, (5) perubahan dari system sentralisasi ke system desentalisasi, (6) perubahan institusional ke bentuk bantuan pribadi, (7) perubahan demokrasi wakil ke partisipatoris, 8) perubahan hirarki-penjaringan, (9) perubahan utara-selatan, (10) perubahan atau ke majemuk.

Pembelajaran di era revolusi 4.0 atau disebut juga era disrubsi yang cirricirinya antara lain: (1) self directed yakni kegiatan dalam pemebalajaran karena ada unsur kebutuhan, (2) multi source yakni pembelajaran menggunakan berbagai sumber pembelajaran dan media pembelajaran, (3) life long learning yakni pembelajaran sepanjang hayat, (4) ICT yaki kegiatan belajar mengajar menggunakan teknologi informasi, (5) motivasi, (6) Attitude, (7) Adaptative, (8) mempunyai Growth Mindset (Wibawa, 2018).

Dalam menghadapi tantangan revolusi industry 4.0, menurut Muhadjir Effendy (2018) perlu merevisi kurikulum dan menambahkan kompetensi antara lain: (1) peserta didik mampu berpikir kritis, (2) peserta didik mampu berpikir kreatif dan inovatif, (3) peserta didik mempunyai keterampilan dalam berkomunikasi dengan baik, (4) peserta didik mampu bekerjasama atau berkolaborasi, (5) peserta didik mandiri mempunyai rasa kepercayaan diri yang tinggi.

Adapun upaya yang dapat dilakukan untuk menghadapi tantangan era revolusi 4.0 dalam bidang pendidikan antara lain:

1 Era disrubsi teknologi revolusi 4.0: Indonesia harus mampu meningkatkan kualitas SDMnya dengan berbasis teknologi.

2 Literasi revolusi 4.0: dalam pendidikan harus ada perubahan literasi lama ke system literasi era revolusi 4.0 meliputi literasi data, literasi teknologi dan literasi humanities.

3 Kebijakan dalam perguruan tinggi, meliputi:

a. Perubahan paradigm Tri dharama yang ada di Perguruan tinggi di sesuaikan dengan era revolusi 4.0, 
b. Reorientasi kurikulum: literasi digital dan coding, ekstrakurikuler, entrepreneurship.

c. Hybried/blended learning: integrasi menggunakan teknologi dalam kegiatan belajar mengajar dan di sesuaikan dengan masing-masing peserta didik.

d. Hubah serta Bimtek (Belmawa) (Yusnaini \& Slamet 2019).

Pendidikan era revolusi 4.0 merupakan fenomena dimana manusia dan mesin saling disejajarkan dalam memperoleh jawaban atau solusi melalui inovasi. Pendidikan pada tingkat dasar sampai perguruan tinggi mengubah kurikulum sesuai tantangan era revolusi 4.0, perubahan ini diharapkan menciptakan bibit bibit SDM yang mampu bersaing di era revolusi 4.0.

Guru sejarah dalam melakukan kegiatan belajar mengajarnya harus sesuai dengan bidang yang diampu yaitu mampu mengungkapkan suatu peristiwa sesuai dengan fakta yang ada di lapangan. Kemampuan yang dimiliki guru sejarah ialah mampu mengintegrasikan nilai-nilai karakter melalui peristiwa atau tokoh pahlawan yang bisa dijadikan suri tauladan kepada peserta didik. Guru sejarah harus menguasai benar tentang materi pembelajaran yang akan diajarkan, dan mempunyai kompetensi yang menunjang dalam mengajar, agar bisa dipahami oleh peserta didik. Melalui pendidikan formal diharapkan mendorong kesadaran sejarah pada peserta didik, sehingga dapat menumbuhkan semangat cinta tanah air atau nasionalisme. Hal ini tentu saja mengarah kepada nilai karakter yang harus ada atau di miliki oleh peserta didik. Sedangkan pendidikan karakter memerlukan suri teladan hidup yang ada pada guru khususnya guru sejarah. Oleh karena itu, untuk mencapai hal itu, diperlukan kerjasama baik di lingkungan sekolah maupun guru sejarah itu sendiri dalam meningkatkan kompetensi yang dimiliki serta melek tehnologi.

Kemajuan teknologi berkembang dengan cepat, tetapi peran seorang guru tidak bisa tergantikan. Tugas guru tidak hanya mengajarkan pengetahuan saja, tetapi menanmkan nilai-nilai karakter dalam diri peserta didik, bisa memanfaatkan teknologi yang semakin maju dan mengarahkan ke hal-hal yang positif yang 
berguna bagi kehidupan sehari hari peserta didik. Peran guru dalam menyosong Revolusi industri 4.0 setidaknya mencakup empat hal, yakni

1. guru memiliki kemampuan dalam melakukan penilaian komprehensif. Penilaian tidak hanya mengarah pada aspek pengetahuan peserta didik saja, tetapi harus bisa menggali potensi pengetahuan, ketrampilan, serta karakter peserta didik. Penilaian di tuangkan dalam sebuah laporan yang nantinya bermanfaat sebagai tolak ukur untuk kemajuan prestasi akademiknya;

2. guru mempunyai kompetensi abad 21 yang meliputi: (a) karakter yakni guru sebagai role model peserta didik harus mempunyai akhlak yang baik, (b) ketrampilan yakni guru harus memiliki ketrampilan dalam mengajar, yang antara lain mampu mempunyai ketrampilan berpikir kritis, ketrampilan berpikir kreatif, kolaboratif serta adanya komunikasi, (c) literasi yakni wadah kreatif guru untuk menuangkannya dalam pembelajaran yang variatif;

3. guru mampu menyajikan modul yang sesuai kondisi siswa;

4. guru mampu melakukan Autentic Learning yang inovatif yakni guru memiliki kompetensi dalam menyajikan pembelajaran yang inovatif (Kompasiana,com, 27 November 2018).

Peran guru amat strategis dalam menyonsong era revolusi 4.0. Ia dituntut mempunyai kemampuan dalam mengembangkan kompetensi yang dimilikinya. Guru harus inovatif dan kreatif dalam pembelajarannya dan bisa memanfaatkan teknologi yang semakin maju. Pemanfaatan teknologi digital di kenal dengan sistem siber, system ini berjalan kontinyu tanpa batas. Jangan sampai tertinggal dengan negara lain yang sudah siap menghadapi tantangan era revolusi 4.0 ini. Guru sejarah harus mampu meningkatkan kualitas potensi yang di miliki peserta didik, salah satunya yang bisa dilakukan ialah pada ketrampilan berpikir tingkat tinggi. Meningkatkan kualitas pembelajaran dengan ketrampilan berpikir tingkat tinggi merupakan upaya meningkatkan kualitas pembelajaran dalam pendidikan di Indonesia. Pembelajaran yang berfokus pada ketrampilan berpikir tingkat tinggi atau HOTS (Higher Order Thingking Skill) dapat juga menumbuh kembangkan penguatan nilai karakter dalam tantangan era revolusi 4.0. 
Kemendikbud dalam peringatan Hardiknas 2018, mengungkapkan:

"Dalam penguatan SDM, terbentang tantangan internal maupun eksternal. Tantangan secara internal ialah tergerusnya nilai ketajaman akal budi serta kekukuhan mentalitas. Contohnya, anak-anak kita terpapar dan terdampak oleh informasi dari medsos. Dalam menjawab tantangan ini sejak awal Kemendibud telah meneguhkan akan pentingnya pendidkan karakter serta literasi, hal ini sejalan dengan revolusi karakter bangsa yang merupakan bagian dari program Nawacita Presisden dan Wakil Presiden”

Laporan World Economic Forum dalam Cristian (2018) menyebutkan bahwa fokus pendidikan dalam mengahadapi revolusi industri 4.0 antara lain

1. pendidikan bukan hanya mengajarkan pengetahuan namun mengajarkan bagaimana berpikir dan berkreasi,

2. pendidikan memiliki fire power guru yang kompeten. Peran guru yang awalnya hanya pengajar berubah menjadi mentor dan fasilitator,

3. pendidikan yang bisa menyesuaikan dengan tuntutan zaman: pemanfaatan tekhnologi semaksimal mungkin,

4. pendidikan mengadopsi literasi digital dan coding,

5. pendidikan yang berfokus kepada pengembangan karakter. Guru sejarah harus paham benar tentang peningkatan kompetensi yang dimiliki sehingga tidak ketinggalan.

Guru sejarah tidak hanya memfokuskan pemberian ilmu pengetahuan, tetapi menginspirasi, memotivasi, memberi teladan, dan mampu mempersiapkan peserta didik sebagai manusia yang berkarakter. Para guru juga harus bijak dalam memanfaatkan teknologi yang ada sehingga perannya tidak bisa digantikan oleh mesin.

\section{SIMPULAN}

Era revolusi industri 4.0 membawa banyak perubahan dalam setiap aspek kehidupan di dalam aktifitas manusia. Perubahan ini bisa kita manfaatkan untuk menjadikan semangat dalam bidang pendidikan agar menciptakan daya kreativitas tinggi, sehingga dapat melahirkan para guru-guru yang profesional dan 
berkarakter. Berkaitan dengan hal ini, guru sejarah ditantang untuk mempersiapkan SDM yang berkualitas tanpa meninggalkan nilai-nilai karakter bangsanya. Oleh karena itu, peran guru yang professional sangat penting untuk mengadapi setiap tantangan menjadi peluang. Upaya ini dapat diwujudkan melalui pelatihan guru secara kontinyu dan berkesinambungan serta mengubah sistem budaya dalam institusi pendidikan menjadi kultur yang berinovasi tinggi.

\section{DAFTAR PUSTAKA}

Asmani, J. 2011. Buku Panduan Internalisasi Pendidikan Karakter Sekolah. Jogjakarta: Diva Press.

Asmani, J.M. 2011. Buku Panduan Internalisasi Pendidikan Karakter di Sekolah. Yogyakarta: Diva Press.

Balitbang Puskur. (2010). Pengembangan Pendidikan Budaya dan Karakter Bangsa: Pedoman Sekolah. Jakarta: Kemdiknas Balitbang Puskur.

Effendi, Muhadjir. (2018, Mei 2). Mendikbud Ungkap Cara Hadapi Revolusi 4.0 dalam Pendidikan. https://www.republika.co.id/berita/pendidikan/education.

https://biroumum.kemendikbud.go.id/web/files/sambutan-mendikbud-hardiknas2018.pdf. Diakses tanggal 11 Agustus 2019.

Kasasi, R. 2018. Discrubtion ( $9^{\text {th }} e d$ ). Jakarta: Gramedia.

Kesuma, D. 2013. Pendidikan Karakter : Kajian Teori dan Praktik di Sekolah. Bandung: PT. Remaja Rosdakarya.

Lantip, A. (2018, November 17). Kompetensi Guru di era revolusi 4.0. Kompasiana,

https://www.kompasiana.com/altip/5bfcab25aeebe161c772f98f/4kompetensi-guru-di-era-revolusi industri-4-0.

Megawangi, R. 2007. Semua Berakar Pada Karakter "Isu-isu Permasalahan Bangsa". Jakarta: Lembaga Penerbit FE UI.

Nas, C.F., dkk. 2019. Revolusi industry 4.0 dan Respon Institusi Pendidikan Dasar dan Menengah. Jurnal Pendidikan Penabur No 31/Tahun ke 17/Desember 2018.

Pusat Penegembangan Kurikulum. 2010. Pedoman Pengembangan Pendidikan Budaya dan Karakter Bangsa bagi Sekolah. Jakarta : Kementrian Pendidikan Nasional.

Rajkumar, R., Lee, I., Sha, L., \& Stankovic, J. 2010. Cyber physical system : The next computing revolution. Proceedings of the 47th Design Automation Conference, DAC 2010, Anaheim California, USA. 
Ryan, K., \& Lickona, T. (Eds.). (1992). Character development in schools and beyond (Vol. 3). CRVP.

Samani, Muchlas, dan Hariyanto. 2013. Konsep Dan Model Pendidikan Karakter. Bandung: PT Remaja Rosdakarya.

Slameto. 2015. Belajar dan Faktor-Faktor yang mempengaruhinya . Jakarta: Rineka Cipta.

Soziduhu Gulo. (2019, Juni 3). Tantangan Pendidikan di Era Revolusi 4.0. https//www.kompasiana.com/sozi/5cf4846995760e76e2037e9/tantanganpendidikan-di-era-revolusi-4.0.

Tjandrawina, R.R. (2016). Indutri 4.0 Revolusi Industri abad ini dan pengaruhnya pada bidang keseharan dan bioteknologi. Jurnal Medicinus, Vol 29, Nomor 1, Edisi April.

Wibawa, S. 2018. Pendidikan dalam Era Revolusi Industri 4.0. Indonesia.

Yahya., M. 2018. Era Industri 4.0 Tantangan dan Peluang Perkembangan Pendidikan Kejuruan Indonesia. Makalah disajikan pada sidang terbuka luar biasa senat Universitas Negeri Makasar.

Yusnaini \& Slamet. 2019. Era Revolusi Industri 4.0: Tantangan dan Peluang Dalam Upaya Meningkatkan Literasi Pendidikan. Prosiding Seminar Nasional Pendidikan Program Pascasarjana, Universitas PGRI Palembang: 12 Januari 2019. Hal 1081-1082. 